\title{
Introducing Formal Tax Education in Secondary School: A Survey on Malaysian Public's Perception
}

\author{
Rani Diana Othman ${ }^{1}$, Zubaidah Ismail ${ }^{2}$, Nurul Hidayah Ahamad Nawawi ${ }^{3}$ \\ \{diana067@uitm.edu.my ${ }^{1}$, z.ismail.ecu.edu.au²,nurulhidayah@uitm.edu.my ${ }^{3}$ \} \\ Universiti Teknologi MARA, Melaka, Malaysia ${ }^{1}$ \\ Edith Cowan University, Western Australia ${ }^{2}$ \\ Universiti Teknologi MARA, Melaka, Malaysia ${ }^{3}$
}

\begin{abstract}
Taxpayers' compliance level of a country reflects its citizens' knowledge about taxation system and, their connection and trust towards the government. However, low compliance level of individuals' and companies has raised the question of the adequacy and effectiveness of citizen tax knowledge in Malaysia and whether tax education is warranted. This study is an overview on the Malaysian public's perception towards introducing formal tax education in secondary schools. First, it looks at current taxpayer's tax learning experience and their opinion on whether a formal approach in teaching taxation should be introduced. Second, this study also evaluates their opinion, on hindsight, if early tax education would have benefited them when they became liable to tax. Third, the public's perception on the importance of taxation as compared to other related financial literacy knowledge is also evaluated. Findings shows that more than $90 \%$ of respondents agreed that early and formal tax education will provide them and future taxpayers with better understanding of the taxation system and their responsibility towards taxes. It is recommended that the Ministry of Education, the Inland Revenue Board of Malaysia (IRBM) and other related tax agencies should work together towards formally establishing tax education curriculum in secondary school in order to enhance future taxpayers' consciousness towards taxes.
\end{abstract}

Keywords: Tax compliance, tax education, secondary school, curriculum, Inland Revenue Board of Malaysia

\section{Introduction}

Tax non-compliance is an everlasting phenomenon faced by all tax administrators in the world as it can never be completely eradicated. Among factors that caused tax non-compliance are lacking of confidence, lacking of awareness, limited enforcement activities, fear of punishment, perception on the fairness of tax system and also morale factors. In order to overcome these issues, more countries have developed various tax education strategies in reaching out to inform and engage not only present, but also future taxpayers. These strategies were shared in Building Tax Culture, Compliance and Citizenship: A Global Source Book on Taxpayer Education [1]. Tax education is perceived as the best and cost-effective way to overcome tax non-compliance due to the fact that, combating tax evasion or chasing potential taxpayer with minimal contribution would likely drain more resources and costs more than the benefit it will bring. Tax education will also bring long-lasting effect since education is able to strengthen feelings of responsibility and pride towards taxpayers' contribution to the country. 
Tax education is defined as a teaching and learning process and instrument of democratic vanguard [2]. Its roles are to strengthen social cohesion through building a collective and participatory reflection on the social and economic role of taxation. It should also represent an effective management of public resources and lead to a relationship of trust between state and citizen. Taxpayer education is also perceived as the bridge that links the aspiration of tax administration and citizens and at the same time is able to transform the tax culture of a country. Establishment of tax education is very important to support any tax system since it helps to ensure high voluntary tax compliance and sufficient tax collection of a country. According to [3] education can strengthen norms that are positively correlated with tax compliance such as honesty, morality, national pride, concern for others, and fairness. This is in-line with the taxpayer education objective proposed by the Organisation for Economic Cooperation and Development (OECD) which is targeted to foster attitudes of commitment to the common good, emphasising the social value of tax and its link to public expenditure [1].

Prior studies suggest that tax education is able to give an impact on taxpayer's attitude towards tax compliance behaviours since it is able to help them in understanding the tax system better [4][5]. Another finding shows that with reasonable understanding of the tax laws, individuals are more willing to respect the tax system, and become more tax compliant [6]. In contrast, lacking of tax understanding causes tax non-compliance or tax evasion which later results in the government losing revenue and being unable to offer basic social services to the people [7].

This study suggests that tax education can be informally and formally provided to taxpayers. The tax administrator of a country is perceived to be the main tax education provider as it shoulders the responsibility to educate the general public as a whole. Tax education by the IRBM is provided through online service, talks, seminars, workshops, Business Support Unit, service counter, Taxpayers' Service Month and collaboration programs with other related parties such as tax practitioners and Ministry of Education. However, these forms of tax education are informal and not compulsory to all citizens and offered based on the needs of specific types of taxpayer. As the consequence, not all citizens will have the same understanding on the rationale of paying tax and therefore affect their moral attitude towards taxes. In contrast, a formal tax education provider would be an authorised institution that is able to ensure compulsory tax education through a systematic approach of national curriculum, approved by the government. In line with previous studies [8][9], the most effective formal tax education provider should be the schools and tertiary institutions. Through this formal tax education, structured and standardize tax knowledge can be systematically disseminated. In order to establish a formal tax education, a strong collaboration between the tax administrator and the Ministry of education is highly [1].

Several countries such as the United States of America, Sweden, Finland, Britain and Japan have initiated such collaboration in order to ensure continuous enhancement of tax education and sustain adequate levels of tax compliance [10]. The most developed tax education system in the world is represented by United States of America. Through the formation of the 'Teaching Resources Committee' by the American Taxation Association, tax educators are supported in term of teaching and research projects. The Internal Revenue Service and the American Tax Authority have also developed interactional education kits and educational sites for high school students to understand the basic, rationale, nature and 
consequences of taxes [11].

The introduction of Tax Digital in United Kingdom has also resulted in its Her Majesty's Revenue and Customs (HMRC) developing and disseminating Tax Facts education programme for teenagers in 2015 and Junior Tax Fact in 2016 for primary schools. The project was sponsored by the Chartered Institute of Taxation (CIOT) which believes that the tax knowledge gap needs to be addressed and tax education introduced as part of formal education in the national curricula. In addition to that, Tanzania has also reviewed its primary and secondary school's curriculum focusing on aspects of tax education. Supported by Action Aid Tanzania and Tanzania Education Network (TEN/MET) a conceptual framework on the basic tax knowledge has been developed to be taught in school [9]. Similar strategies were also implemented by South Africa which reportedly established a comprehensive tax education specific for the school level [12].

This study calls for serious attention towards establishing formal tax education in Malaysia due to the pervasive tax compliance issue which was strongly addressed by the IRBM in Malaysia National Tax Seminar 2018. With a theme of "Tax Revenue: Our Responsibility", the tax administrator posed concern on the low level of tax compliance among Malaysian taxpayers. The statistic in Table 1 shows that only $15.24 \%$ of individual labour force and $16.27 \%$ of registered companies are actually paying tax in 2018. Another statistic on the percentage of tax payment was highlighted by the Tax Reform Committee which shows only $21 \%$ of companies and $15 \%$ labour force were subjected to income tax [13]. This statistic was later justified due to Malaysia's narrow tax base and very low incomes of taxpayers. However, regardless of the provided reasons, issues on 79,786 individuals, companies, organisations, cooperatives and others who have yet to pay tax, attracted this tax researcher's' attention [13]. This is because, despite the impressive increasing amount of tax collection, (from RM123 Billion in 2017 to RM137 Billion in 2018) the reported low level of taxpayers' compliance is very alarming. In other word, the increase in tax collection does not appear to be correlated to the reported tax compliance level. Therefore, from the tax education perspective, there are concerns that the high tax collection reported by IRBM is based on 'non-voluntary' compliance through threat of penalties or offers from amnesty programs such as Special Voluntary Disclosure. Such non-voluntary compliance intensifies the question relating to the effectiveness of tax education currently available in Malaysia.

Table 1. Individual and Companies Compliance Level 2018

\begin{tabular}{lrlr}
\hline & \multicolumn{1}{c}{ Individual Taxpayer } & Companies Taxpayer \\
\hline Total Labour & 14.9 Million (100\%) & Registered & l,199,852 (100\%) \\
Force & Company & $195,216(16.27 \%)$ \\
Paying Taxes & 2.27 Million (15.24\%) & $\begin{array}{l}\text { Registered and } \\
\text { Paying Taxes }\end{array}$ \\
Not Paying Tax & 5.03 Million (33.76\%) & $\begin{array}{l}\text { Registered but Not } \\
\text { Paying Taxes }\end{array}$ & $1,004,636(83.73 \%)$ \\
Not Registered & 7.6 Million (51\%) & \\
\hline
\end{tabular}

Currently IRBM provides education programs for schools such as Tax Camp, Junior Tax Officer in Kidzania, speech competition, quizzes and visit to IRBM office in Cyberjaya located in Kuala Lumpur. However, those forms of tax education are informal in nature and their effectiveness towards promoting voluntary compliance to all level of taxpayers is still 
under evaluation. Therefore, consistent with the suggestion by OECD, an early and formal tax education should be implemented with strong support by Ministry of Education. It is important to note that a number of previous studies have continuously emphasised tax education reform in Malaysia. However, after a long 26 years since, Barjoyai's suggestion, the formal introduction of tax education in school remains unheeded [4]. This study re-visits formal tax education research in Malaysia, and reports initial results of public's perception on the introduction of formal tax education in secondary schools. Besides assessing taxpayers' confidence level in filing tax returns, this study will also compare their perception on the importance of taxation in relation to other components of financial literacy knowledge.

\section{Literature Review}

\subsection{Tax compliance and tax education research in Malaysia}

Tax compliance behaviour is contributed by several factors such as economic, legal, demographic and moral attitude. These factors determine taxpayer choice regarding whether to comply with tax or to commit tax evasion [14]. In general, tax compliance factors can be categorised into economic and non-economic factors. Economic factors affect compliance through penalties and sanctions imposed by tax enforcement activities such as audit and investigation [15][16]. However, non-economic factors rely on behavioural and socioeconomic factors such as knowledge, attitude, ethics, demographic variables (age, gender, ethnic and occupation) and also taxpayer's perception on tax complexity [17]. There are many studies on the effect of both main factors towards tax compliance. The studies which includes tax knowledge and tax education, show significant positive impact of this variable towards tax compliance [18], [19].

In Malaysia, there is a lack of research, to the researchers' knowledge that evaluates the effectiveness of informal tax education provided by the IRBM towards enhancing tax compliance in Malaysia. Therefore, tax education research in Malaysia is very limited as it is only confined to the evaluation of self-reported survey on the effectiveness of tax education provided at the tertiary level. Tax education research in Malaysia was initiated by [4], [20]. They focussed on the introduction of tax subject to Malaysian's undergraduates, regardless of their academic background. The study of [4] opined that tax education is more important than geography or geometry as it is a universal subject that is needed by everybody including future potential taxpayers. His study found that tax education is very important in enhancing understanding and compliance towards tax. A proposal for tax education to be introduced at the school level in order for students to be more literate towards tax. A study was conducted to investigate the effect of tax education towards taxpayer's compliance behaviour [6]. This study focussed on accounting students who had yet to formally sit for their taxation course. The finding confirms the existence of a positive relationship between tax education and tax compliance. They also suggested for the social science discipline in tertiary education, to offer a preliminary tax course as a core subject.

This research journey is followed by [21] who investigated the needs for tax education of adult learners amongst non-accounting students. Besides assessing their level of tax knowledge, the survey found that more than $60 \%$ of the respondents are willing to learn about 
tax. As this study found that only $23.7 \%$ of respondents has high level of tax knowledge, the result suggests more emphasis on the importance of tax education especially in keeping to the newly implemented self-assessment system in Malaysia. The first large scale study on tax education in Malaysia was performed by several researchers as it involves three main public universities in Malaysia [22]. Questionnaire were distributed to 1,575 students in nonaccounting discipline and the results, supports previous studies, where a majority of the respondents are willing to take tax course as an elective paper. Besides the needs for tax education among non-accounting students, this study also provides information on the topics that respondents are interested to learn and the way they prefer tax education to be taught. Compared between these two studies, the percentage of respondent with high level of tax education in this study is lower at only $10.46 \%$. Therefore, this study provides another concrete reason for introduction of formal tax education for non-accounting curriculum in tertiary education [21], [22].

Only study is available which assesses public perception on the importance of general tax education and the best medium used by IRBM to educated taxpayer [23]. This study investigates the way to facilitate taxpayer towards implementing their responsibility in filing of tax return and tax payment. The findings show that taxpayers basically depend on textbased information distributed by IRBM via printed pamphlets and advertisement, including news-feed provided in the website to facilitate their compliance. In terms of medium of dissemination, $55 \%$ and $46.6 \%$ of respondents suggested that television and radio would be the most effective way to educate them regarding taxation. However, despite of their concern on the country's tax collection, $61.67 \%$ of the respondents were not willing to attend program organised by IRBM as it is costly and time consuming, besides claiming that they already have basic knowledge on taxation. Therefore, the above-mentioned study proposed an enhancement of tax education program organised by the IRBM.

With the exception of above-mentioned study, the other Malaysian studies highlighted the importance of formalising tax education in Malaysia. However, all of these studies focussed on formal tax education at the tertiary level and none, at school level. Justification was claimed that tax knowledge is too advanced and specialized to be included in primary and secondary curricula [24]. This is consistent with [25] which found that children, ranging from 10 to 15 years old, are unable to fully comprehend the nature and purpose of taxation. However, despite these claims, the importance of educating the young and its impact towards the future of a country should not be underestimated. Inadequate education on tax morality and tax system will resulted in negative perception towards the government and the function of taxation.

To date in Malaysia, formal tax education at the school level has yet to be established and there is a lack of research studies on the effectiveness of informal tax education provided by IRBM. With the intention to fill this gap, this study sets out to evaluate the effectiveness of informal tax education received by taxpayers during secondary school and whether it helped them to fulfil their tax responsibility. The findings are expected to provide more insights in the quest to formally introduced tax education in secondary school as a method of combating noncompliance and tax evasion. Non-compliance usually relates to unintentional error during filing tax return and is caused by lack of knowledge and confidence in tax information [26]. As highlighted by [27] and Azubike [28], ignorance about tax has become a significant problem in Nigeria since taxpayers are not sufficiently educated and enlightened on the 
provision of the various tax laws in the country. Whereas tax evasion relates to negative moral attitude of taxpayer towards the government [17]. The consequence of both issues is that they will later lead to a major issue of taxation, known as the tax gap, defined to be the difference between the tax owed and taxes paid [29]. In addition, the tax gap problem will result in losses of revenue, unequal distribution of social welfare and distort the future of a country [30].

\subsection{Role of the IRBM - The Main Informal Tax Education Provider}

As the main informal tax education provider in Malaysia, the IRBM has established various tax education programs, using various media to reach out to taxpayers. Even though these tax education programs have been continuously organised either solely by IRBM or through collaboration with other agencies, the number of programs and it's out-reach coverage is very limited, especially for schools or young generations. Nevertheless, in order to educate secondary school student, the IRBM and MOE had jointly organised "Young Tax Camp" through the Malaysian Tax Academy since the year 2011. This tax education program involves participants in various tax-related activities including Taxplore Race (activities in the form of a Tax-themed Explore Race) and participation in e-Filing simulations. Even though this program was reported to increase the number of young taxpayers submitting their Income Tax Returns [31], it does not involve all secondary school student. It is held only once a year and caters to only around 200 to 300 participant including school teachers from selected schools. Another tax education program meant for school students is the Junior Tax Officer simulation, held in Kidzania, Kuala Lumpur. This simulation game teaches the primary school student on the job tasks of a tax officer and the role of tax towards the development of the country. Other tax education program organized for school students are speech competitions, quizzes and visit to IRBM's office. It is undeniable that these tax education programs give an impact towards the young tax payers' compliance behaviour, but such exposure is very limited as it's only experienced by those students from schools selected to attend the tax camp and who have the opportunity to visit IRBM's office or Kidzania in Kuala Lumpur.

Besides tax education programs for schools level, continuous tax education programs were also implemented for individuals, companies, tax agents, employers and the taxpayers. The objectives are to reduce the gap between taxpayers and the tax administrator, as well as to increase awareness on tax responsibility and facilities offered by IRBM. Most of these activities are held by the IRBM's Customer Service in the headquarters and branches based on specific needs of the taxpayer. Among the most highlighted education program is the Taxpayers' Service Month where IRBM will provide longer service period at their service counters, including weekends. This program is very useful in assisting taxpayers in filing correct tax returns. During the implementation period of this program, more information is disseminated to the public through various media, including radio and television programs to promote submission of tax returns. For business taxpayers, the IRBM organised workshops with free consultancy service to help them in organising and managing business documentation and accounting records. Business taxpayers were also guided in the preparation of prepare correct financial statements as a basis for tax computation.

In conclusion, the IRBM's education programs target every taxpayer level in order to promote tax compliance through adequate tax information. The summit of the IRBM's tax education is the National Tax Seminar organised after the tabling of the Yearly National Budget in the parliament. Besides providing and updating latest information in relation to 
taxation, this seminar is conducted to focus on areas that has pending issues for discussion and resolution.

\subsection{Role of Schools - The Main Formal Tax Education Provider}

Schools have traditionally function as the main avenue for the dissemination of knowledge to the public. This is because, schools offer a well-structured curriculum and lesson plan that will suit the appropriate age levels of students [32]. In the context of tax education, school is suggest to be the best institution to provide formal tax education through a well-developed and structured tax education framework. Malaysia's National Secondary School system, require all students to complete core subjects (such as science, mathematics or civic) besides other electives based on their study stream. Since taxation is the fundamental element in financial literacy and a universal knowledge that it is needed by everybody in exercising their responsibility towards taxes, it should be included as a core subject in the school education system. Introducing formal tax education at school level, will enable the government to reach all citizens of Malaysia. This is also in-line with the function of government schools towards effectively disseminating government policies.

The school level is the best place to introduce tax education due to the age factor. In South Africa, a study opined, since the population of the young (ages of 5 to 24 years old) and also future taxpayers attending educational institutions is very high, the decision to implement tax education at school or early secondary level will have better chances to succeed [33]. The advantage of disseminating tax knowledge at this level will increase the tendency for higher tax awareness and promote positive tax compliance behaviour as a norm. The current study is going to support the study done in South Africa towards introducing tax education to secondary school students due to fact that some of them will immediately start their career and will be liable to tax. Therefore in this situation, having tax knowledge at secondary school age of $12-18$ years old will benefit them in exercising their responsibility towards taxes. Other reason to support educating school students is because this age group is conducive to developing a positive mind set regarding ethical and legal right of taxation. This will later help them to balance between personal interest and benefit to the country. This understanding should not be imposed at a later age of their life, as it will be less effective in attitude and mind set formation.

Another important factor, is the significant role of the teacher in providing education to the students. The Protocol for Observing Teaching Roles was designed and outlined that a teacher play the roles of communicator, motivator, behavioural controller, guidance provider and advisor [2]. At the same time, the student describes the teacher who impact their lives as a person with intelligent, affection, commitment, passion and a person with high ethics. Ethics applies to a person's presumably free and responsible behaviour. Ethics is a philosophical discipline that is aimed at doing good deeds as the main part of human behaviour. A teacher teaches in two dimension of ethics which is general ethics and profesional ethics where both principles and guidelines aim to do what is right for their stakeholder or to their own profession. If a teacher believes that tax evasion is wrong, than he or she will consider preventing tax fraud as one of his/ her role. More importantly as a teacher is always being portrayed as a role model, his or her strong belief in tax ethics will have a huge impact towards producing more tax responsible taxpayers in the future. This is supported 
by educational psychologists who claim children are not born with ethics or morality, but they need to be taught on ethics and moral quality in school [9].

School student should be exposed to the Malaysian tax system, including the reasons why taxes are being collected, the roles of taxes, facilities provided by the government through tax, how to minimize tax liability and how to avoid tax evasion. This is to ensure that they will grow with better understanding of taxes and the importance of tax planning as part of financial literacy knowledge. Tax education's benefit is life-long and at the same time provides a win-win situation to the government. Providing more resources in educating future taxpayers towards positive compliance behaviour will reduce tax enforcement costs of the government and at the same time ensures effective tax collection. Therefore, it is very important for the government to manage its tax compliance level through the establishment of a good tax education policy. An example from Japan also shows that introduction of tax education to school children is able to develop tax morality and responsibility in future taxpayers [34]. Other high level tax compliance countries in the world, such as Canada, United States, Switzerland and New Zealand have developed tax education programs in the early stage of education to prepare their young in becoming a responsible adult in the future.

With the above discussion, this study is intended to close the study gap on the introduction of formal tax education at the school level in Malaysia. But, more importantly, it tries to bring the attention of related parties on the importance of tax education to the young in order to ensure higher voluntary tax compliance in the future. This study is well aware of the long procedures and processes required to develop and implement formal tax education in Malaysian secondary schools. But with the alarming low level of tax compliance among Malaysian taxpayer, this journey must be started before it's too late.

In general, this study is motivated by the lack of academic literature in the field of tax education at the school level in Malaysia. More specifically, this study aims to:

1. investigate the existence and type of tax education received by the public while they attended secondary school;

2. ascertain whether the public desire a formal form of taxation education during their secondary schools;

3. determine the confidence level of the public during their first experience filing their tax returns;

4. identify the public's perception on the need for tax knowledge as compared to other areas of financial literacy.

\section{Research Methodology}

Survey was selected as the appropriate methodology for this study due to its effectiveness in relation to the construction, administration and collection of the data. It is also selected as it is consistent with previous studies investigating the same issue [24], [25]. The survey questions were adapted from Morgan and Castelyn (2018) comprising 27 questions based on the following components: 
i) Demographic information

ii) Secondary school information

iii) Previous tax education exposure during secondary school

iv) Level of tax knowledge, perception towards introduction of tax education in school and comparison of importance of tax versus other financial literacy knowledge

v) Opinion on Malaysian tax administration

The survey was administered via google.doc form primarily targeting part-time postgraduate students in Masters in Accounting and Masters in Executive Business Administration in UiTM Shah Alam, Selangor and Melaka. Most previous studies on tax education in Malaysia involved survey being distributed to undergraduates. However, taking into consideration the low likelihood of undergraduates having experience in administrating tax and other financial literacy issues, this study believes that post-graduates students can better reflect the importance of tax education in Malaysia. The survey was distributed to 50 postgraduates students from both programs. In order to reach a broader base of voluntary respondents, the survey was also distributed to public group, via Whatsapp application. Based on google.doc responses database, 76 responses were received and analysed. The theoretical framework for this analytical methodology is based on identifying, analysing, and reporting themes within the data to better illustrate the relationship between the research questions and the responses.

\section{Findings}

\subsection{Section 1 - Demographic information}

The purpose of this section is to report on the respondents' characteristics and to determine the representativeness of respondent group to represent the public community. Section I of the survey, collects the following information from participants:-

1. Gender of participants

2. Age of participants

3. Marital status of participants

4. Employment status of participants including sector of participants' employment

Analysis on demographic responses shows that $36 \%$ of respondents are male and $64 \%$ are female. The gender percentage corresponds to the proportion of registered students in both masters programs. Higher number of female respondents has been shown in many research studies [35], [36] which may suggest that female taxpayers are more committed and compliant to tax regulation [37], [38].

\begin{tabular}{lcc}
\hline Question 1: What is your gender? & & \\
\hline Category of respondents & Number & Percentage(\%) \\
Male & 27 & $36 \%$ \\
Female & 47 & $64 \%$ \\
\hline
\end{tabular}




\begin{tabular}{lcc}
\hline Question 2: What is your age? & Number & Percentage (\%) \\
\hline Category of respondents & 28 & $37 \%$ \\
$20-35$ years old & 17 & $22 \%$ \\
$36-45$ years old & 28 & $37 \%$ \\
$46-55$ years old & 3 & $4 \%$ \\
More than 55 years old & & \\
\hline & & \\
\hline Question 3: What is your marital status? & Number & Percentage (\%) \\
\hline Category of respondents & 50 & $66 \%$ \\
Married & 26 & $34 \%$ \\
Unmarried & & \\
\hline
\end{tabular}

It was found that $37 \%$ respondents are at the age between 20 to 35 years old, $22 \%$ are at the age of 36 to 45 years old and $37 \%$ are at the age of 46 to 55 years old. Interestingly there are $4 \%$ respondents at retirement age participating in the survey. To further enrich this information, the third question was analysed and it shows that $66 \%$ of respondents are married. As mentioned earlier, the main reason why the survey was distributed to masters level students is due to age factor. A majority of respondents were categorised as matured taxpayer, hence the probability of their income to be in the liable tax bracket is high. Therefore they are expected to have more experience in dealing with the tax system and should be able to give more practical views and objective opinions in enhancing the effectiveness of tax education in Malaysia. The spread distribution of respondent's age (exceeding the age of 25 to over 50 years old) can contribute towards explaining the long history of tax education in Malaysia over time. More importantly, married respondents are anticipated to have a clearer understanding on the importance of taxation towards their children's future.

It is important for the study to assess the respondents' employment status since those who are currently receiving income or engaged in any employment will have more experience in dealing with tax laws and provisions. The highest proportion of occupation categories comes from administrators, followed by educators and teachers. Participants from science technology industry involve doctors, aqua-marine researcher, micro-biology researcher and dentists. $7 \%$ of the respondent are unemployed and part-time master students and another $3 \%$ are retirees. A well distributed employment profile with vast tax experience is expected to reflect public perception on tax education issue. Even though there is no question on the education level of respondents, the employment categories indicate that they are a welleducated group with potential critical insight on the issue.

\begin{tabular}{lcc}
\hline Question 4: What is your employment? & & \\
\hline Category of respondents & Number & Percentage (\%) \\
Administrator & 24 & $32 \%$ \\
Lecturer & 11 & $14 \%$ \\
Business person & 7 & $9 \%$ \\
Accounting/auditor & 7 & $9 \%$ \\
Bankers & 6 & $8 \%$ \\
Science Technology & 5 & $7 \%$ \\
Teacher & 5 & $7 \%$
\end{tabular}




\begin{tabular}{lll} 
Information Technology & 3 & $4 \%$ \\
Service industry & 1 & $1 \%$ \\
Others: & & \\
Full-time student and unemployed & 5 & $7 \%$ \\
Retired & 2 & $3 \%$ \\
\hline
\end{tabular}

\subsection{Section II - Secondary school information}

The second section of the survey is to gain information on the year respondents completed their secondary school and characteristics of their school. Questions asked in this section are as follows:

1. The year that the respondents completed their studies in secondary school

2. The types of secondary school they attended

3. Location of their secondary school

The finding shows $42 \%$ of respondents left their secondary schools between the years 1979 to $1989,19 \%$ between the years 1990 to $1999,24 \%$ between the years 2000 to 2009 and $15 \%$ of them left their secondary school since 2010 . Even though recent school leavers were able to describe their learning experience during secondary school more effectively, this study also expects richer input from those who have long left their schools. Not only can they give opinions based on their own tax education experience, but they also able to continuously assess its consistency and progress based on their secondary school children's experience.

\begin{tabular}{lcc}
\hline \multicolumn{3}{l}{ Question 5: In what year did you complete your secondary school? } \\
\hline Category of respondents & Number & Percentage (\%) \\
$1979-1989(30-40$ years) & 28 & $42 \%$ \\
$1990-1999(20-30$ years) & 13 & $19 \%$ \\
$2000-2009$ (10 - 20 years) & 16 & $24 \%$ \\
$2010-2018(1-10$ years) & 10 & $15 \%$ \\
\hline
\end{tabular}

When asked regarding the types and location of their secondary school, the findings show all respondents went to government school undertaking different study streams. A majority of them went to National Secondary School, 28\% to Religious Secondary School, $15 \%$ went of Fully Residential School and 3\% underwent the technical stream. In terms of location, $48 \%$ of the secondary schools are located in urban areas, $32 \%$ in rural areas and the rest were located in suburbs. This finding shows that the tendency of respondents to be exposed to tax education is very high. Government school is expected to be the main platform for a government to entrust its policy and vision of a country, and with higher accessible to public facilities ( $48 \%$ in urban area), the better chances for these school to be involved with the IRBM informal tax education program. 


\begin{tabular}{lcc}
\hline \multicolumn{3}{l}{ Question 6: What is the type of your secondary school? } \\
\hline Category of responses & Number & Percentage (\%) \\
National Secondary School & 40 & $54 \%$ \\
Religious Secondary School & 21 & $28 \%$ \\
Fully Residential School & 11 & $15 \%$ \\
Technical School & 2 & $3 \%$ \\
\hline
\end{tabular}

\begin{tabular}{lcc}
\hline Question 7: Where is your secondary school located? & & \\
\hline Category of responses & Number & Percentage (\%) \\
Urban & 36 & $48 \%$ \\
Rural & 24 & $32 \%$ \\
Suburb & 15 & $20 \%$ \\
\hline
\end{tabular}

\subsection{Section III - Previous tax education exposure during secondary school}

It is important to note that formal tax education has yet to be given a serious attention in Malaysia. However, Question 8 was posed with assumption that respondents will perceived that any tax knowledge received during secondary school is considered as formal. The following questions were asked in order to get clear perspective on the status of tax education in Malaysia's secondary school and how it progress throughout the period:

1. Did you receive any formal tax education during secondary school?

2. Has your secondary school organised any tax education program collaboration with the IRBM during your study period?

3. Have you been exposed to any of the following information during secondary school?

4. What are the subjects that you learn during secondary school relating to tax?

5. What is your percentage of tax knowledge after completing secondary school?

\begin{tabular}{lcc}
\hline Question 8: Did you receive any formal tax education during secondary school? \\
\hline Category of respondents & Number & Percentage (\%) \\
Yes & 4 & $5 \%$ \\
No & 71 & $95 \%$ \\
\hline
\end{tabular}

The results of Question 8 show that $95 \%$ of respondents claimed that they did not receive any formal tax education during secondary school. It is worth to note that $61 \%$ are those who left their secondary school more than 20 years ago (as in Question 5). This shows that respondents with different periods of secondary school experience, confirm the lack of formal tax education over time. Interestingly, only $5 \%$ of respondents confirmed that they had received some form of formal tax education.

Beside formal tax education, respondents were also asked on their experience receiving informal tax education programs from the IRBM. Surprisingly, none of them have had any experience involving programs organised by IRBM in collaboration with their secondary schools. Despite the fact that all respondents attended government school with more than 50\% of it located in urban area, this low percentage of formal and informal tax education exposure needs to be given serious attention by IRBM. 


\begin{tabular}{lcc}
\hline Question 9: Has your secondary school organised any & tax & education program in \\
collaboration with the IRBM during your study period? & \\
\hline Category of respond & Number & Percentage (\%) \\
Yes & 0 & $0 \%$ \\
No & 75 & $100 \%$ \\
\hline
\end{tabular}

With the assumption that respondents may not know the difference between formal and informal tax education, this study further explored the nature and level of tax education previously exposed to them. Question 10 specifies 7 topics on taxation which cover the definition of tax education in general. Taxation education can be broadly defined as 'a general introduction to concepts and principles of taxation. It covers personal, business and corporation taxation, tax administration, tax assessment, appeal and basic tax planning for individuals and businesses' [22].

Question 10: Have you been exposed to any of the following information during secondary school?

Who is liable to pay tax?

\begin{tabular}{cccc}
\multicolumn{2}{c}{ Yes } & \multicolumn{2}{c}{ No } \\
Number & $(\%)$ & Number & $(\%)$ \\
17 & 23 & 56 & 77 \\
11 & 15 & 63 & 85 \\
9 & 12 & 65 & 88 \\
& & & \\
4 & 6 & 67 & 94 \\
4 & 5 & 69 & 95 \\
4 & 5 & 70 & 95 \\
0 & 0 & 73 & 100 \\
\hline
\end{tabular}

The function of taxation to a country

Type of tax collected by Malaysian

government

Penalties on tax evasion

Type of allowable deduction/relief

Types of taxpayer in Malaysia

How to fill-in tax return

Overall, between $1 \%$ to $23 \%$ of the respondents claimed that they have been exposed to the topics. In question $8,5 \%$ of respondents claimed that they had been exposed to formal tax education, this finding, however suggests that such exposure on the topics were probably received through informal tax education. Among the top three topics, the percentage of respondents exposed to the topics "who is liable to pay tax" is $23 \%$, followed by "function of taxation to a country" (15\%) and "type of tax collected by Malaysian government" (12\%). However, even though respondents were exposed to the prior mentioned topics, other information related to the tax administration such as filing compliance, allowable deduction and types of taxpayers in Malaysia were very limited and still far from the definition of tax education.

To further elaborate on participants' tax knowledge, question 11 was included and responded to by 73 of participants. It was found that 35 participants claimed that none of subjects was in their secondary school curriculum. The rest of the finding shows that tax education has been informally integrated into a number of subjects. Economics and accounting have been reported to be among the highest reported subject beside history and mathematics. However, it is important to note that the first two subjects were offered as an elective to selected study streams and does not constitute the core curriculum. This also means that only a 
small percentage of a given secondary school population would have been exposed to the fundamental information in respect of taxation.

\begin{tabular}{lc}
\hline Question 11: What subjects that you learn during secondary school are related to tax? \\
\hline Subject related to tax & Number of respond \\
Economics & 15 \\
Accounting & 14 \\
History & 8 \\
Mathematics & 7 \\
Commerce & 6 \\
Morale & 2 \\
Science & 2 \\
Islamic Understanding & 1 \\
None of the subject & 35 \\
\hline
\end{tabular}

To conclude this section, question 12 looks into the level of the respondent's knowledge if they were to start working straight after secondary school. The finding shows, without any additional information on taxation, $83 \%$ of respondents will have only at the maximum of $25 \%$ tax knowledge to fulfil their tax filing responsibility. Only $9 \%$ of respondents claimed to have more than $50 \%$ level of tax knowledge to understand the issue of compliance towards tax. As suggested by previous studies, lack of knowledge is correlated to higher noncompliance behaviour, either intentional or unintentionally [34], [39].

\begin{tabular}{lcc}
\hline $\begin{array}{l}\text { Question 12: What is your percentage of tax knowledge after completing secondary } \\
\text { school? }\end{array}$ & Number & Percentage (\%) \\
\hline Percentage of knowledge & 62 & $83 \%$ \\
$0-25 \%$ & 6 & $8 \%$ \\
$>25 \%-50 \%$ & 4 & $5 \%$ \\
$>50 \%-75 \%$ & 3 & $4 \%$ \\
$>75 \%-100 \%$ & & \\
\hline
\end{tabular}

\subsection{Section IV - Level of tax knowledge, perception towards introduction of tax education in school and comparison of importance with other financial literacy knowledge}

Section IV of this survey answers several fundamental issues of this study. This section gathers information of respondents' actual experience in administrating their tax return and their perception of the importance of tax education. The following are the questions put forward in this section:-

13. What is your percentage of tax knowledge when you first fill in your tax return?

14. How did you manage in filling in your first tax return?

15. Are you confident with the information that you provided in your first tax return?

16. Who are the persons helping you in filling-in your tax return?

17. Did you have additional tax knowledge after you finished your secondary school?

18. From where did you obtained those additional tax knowledge? 
19. Do you think it will be more beneficial if you were taught about tax during your secondary school?

20. Do you think that it will be more beneficial if the student is given an early introduction on their roles and responsibility towards tax?

21. Do you think that it will be better if the student is given early information on the benefit of tax to the society?

22. At what level do you think tax education is suitable to be introduced?

23. Of the following, please indicate which is the most important to least important to help you have a good financial understanding for making decisions about your future (with 1 being significantly not important and 5 being significantly important).

To further emphasise on the importance of tax education, question 13 assessed respondents' level of tax knowledge when they first fill-in their tax returns as compared to when they finished their secondary school. In Malaysia, individuals with chargeable income exceeding RM34,000 per annum will start to be liable to pay tax. They must file their tax return via e-filing even though they have had their tax paid in advanced through Scheduler Tax Deduction from their monthly salary. As for secondary school leavers in Malaysia, their average income per month is assumed to be RM1,060 as announced by the Prime Minister's office on 5 September 2018. Therefore, it takes several years before their annual income fall in the lowest tax bracket. It is expected that during that period, their tax knowledge would have improved.

\begin{tabular}{lcc}
\hline $\begin{array}{l}\text { Question 13: What is your percentage of tax knowledge when you first fill in your tax } \\
\text { return? }\end{array}$ & Number & Percentage (\%) \\
\hline Percentage of knowledge & 22 & $30 \%$ \\
$0-25 \%$ & 24 & $33 \%$ \\
$>25 \%-50 \%$ & 14 & $19 \%$ \\
$>50 \%-75 \%$ & 13 & $17 \%$ \\
$>75 \%-100 \%$ &
\end{tabular}

As anticipated by this study, the finding shows that respondents' level of knowledge has increased significantly. Those with tax knowledge level of more than $50 \%$ has increased from $9 \%$ to $36 \%$ and in contrast, those with tax knowledge less than $50 \%$ has reduced from $91 \%$ to $63 \%$. This shows that in order to ensure more taxpayers to become more knowledgeable, compliant and able to avoid unintentional tax non-compliance, further tax education is needed after secondary school. As the main tax education provider in Malaysia, the IRBM needs to evaluate the effectiveness of informal tax education programs provided by them. This is because the finding shows only $17 \%$ of taxpayers have adequate knowledge of more than $75 \%$ to fulfil their filing compliance. This small percentage is considered unsatisfactory.

\begin{tabular}{lcc}
\hline Question 14 : How did you manage in filling-in your first tax return? & \\
\hline Percentage of knowledge & Number & Percentage (\%) \\
Filling-in it myself & 29 & $40 \%$ \\
Filling-in it with the help of others & 40 & $55 \%$ \\
Ask other to fill-in and file it for me & 6 & $5 \%$ \\
\hline
\end{tabular}


With reported level of tax knowledge, respondents were then asked on how they managed in filing their first tax return. Finding shows that $40 \%$ of respondents claimed that they managed to file the tax returns all by themselves. The balance of $55 \%$ depended on others and 5\% who are expected to come from business group taxpayers, have directly instructed other people to file the tax return on their behalf. The Self-Assessment System (SAS) was implemented with the main objective of promoting voluntary tax compliance and in line with that, the system was equipped with online user manual to facilitate e-filing by taxpayers. Therefore in the current tax regime, taxpayers are expected to be more knowledgeable about taxation in order to voluntarily assess and exercise their filing compliance by themselves.

However, it is important to pay attention to the $55 \%$ of respondents that turn to others to help them with their tax return. In Question 15, respondents admitted that they turned to friends (45\%), IRBM officers (31\%) and spouse (21\%) for help. The finding confirms the low level of tax knowledge of respondents in filing the tax return as they admitted that they needed help from others. Nevertheless, this finding also shows that tax education programs organised by the IRBM such as training, 'Taxpayer Service Day' or visits to the IRBM office is effective in improving taxpayers' compliance level.

\begin{tabular}{lcc}
\hline \multicolumn{3}{l}{ Question $15:$ Who are the persons that helped you in filling-in your tax return? } \\
\hline Source of help & Number & Percentage (\%) \\
Friends & 28 & $45 \%$ \\
LHDN Officers & 19 & $31 \%$ \\
Spouse & 13 & $21 \%$ \\
Other family member & 7 & $11 \%$ \\
Tax agent & 4 & $7 \%$ \\
\hline
\end{tabular}

To further discuss the issue of tax knowledge, respondents were also asked about their confidence level in the information provided to the IRBM in their tax returns. Out of 69 respondents who filed the tax returns by themselves and with the help of others, 44 of them (62\%) claimed that they are confident with the information. However, $38 \%$ of them filed their returns despite their lack of confidence. Arguably, this might cause incomplete returns, error in allowable deduction or relief that will be subjected to unfavourable outcomes if audited or investigated. It is crucial to know the area of tax knowledge that they're lacking, in order to understand such phenomenon.

Question 16: Are you confident with the information that you provided in your first tax return?

\begin{tabular}{lcc}
\hline Category of respond & Number & Percentage (\%) \\
Yes & 44 & $62 \%$ \\
No & 27 & $38 \%$ \\
\hline
\end{tabular}

The following questions asked about participants' acquisition of tax knowledge (Questions 17, 18) and their perception of its importance for future generation (Question 19, 20 ). The finding shows that $65 \%$ of them claim that they have gained additional tax knowledge after they finished the secondary school and highlighted the sources. 


\begin{tabular}{lcc}
\hline $\begin{array}{l}\text { Question 17: Did you acquire additional tax knowledge after you finished your secondary } \\
\text { school? }\end{array}$ & \\
\hline Total Responses: 75/76 & Number & Percentage (\%) \\
Category of respondents & 49 & $65 \%$ \\
Yes & 26 & $35 \%$ \\
No & \\
\hline \multicolumn{2}{l}{ Question 18: From where did you obtain those additional tax knowledge? } \\
\hline & Number of responses \\
Category of respondents & 35 \\
Own reading & 34 \\
In tertiary education (university) & 12 \\
Workplace collaboration with LHDN & 5 \\
Courses organised by the IRBM & 4 \\
Taxpayer compliance program by IRBM, & 4 \\
Information from workplace & 4 \\
Others (spouse/friend/IRBM website/television) & \\
\hline
\end{tabular}

The responses show that the main source of additional tax education, was gained from respondents' own reading (35 responses), 34 of them claimed that they received taxation education during their studies at tertiary level and 12 of them improved their knowledge through the IRBM collaboration programs with their workplace. Even though tertiary level education managed to provide additional tax knowledge as suggest by previous studies [4], [21], [22] it is only offered in programs with majors in Accounting and Business/Finance Programs [6] Therefore this finding provides further support for non-accounting programs at the tertiary level to offer taxation as their core subject. Collaboration programs between participants' workplace and the IRBM have also been reported as an important source of tax education after school. However, the effectiveness of other tax education activities (courses, IRBM website or television program) by the RBM need to be further evaluated in order to increase its effectiveness in disseminating information to the public.

The respondents were then asked their opinion if they would find it more beneficial, if they were exposed to tax knowledge at an early age in secondary school. Finding shows, 89\% of respondents agreed on the benefit of tax education for them and also for the future generation. They believed the introduction of taxation studies in secondary schools would improve the young generation's understanding on their roles and responsibilities as future taxpayers. They also agreed that it will help the young in understanding the importance of taxes towards developing the society and the country.

Question 19: Do you think that it will be more beneficial if you were taught about tax during your secondary school?

\begin{tabular}{lcc} 
Category of responses & Number & Percentage (\%) \\
Yes & 67 & $89 \%$ \\
No & 8 & $11 \%$ \\
\hline
\end{tabular}




\begin{tabular}{lcc}
\hline Question 20: Do you think that it will be more beneficial if students & are given an early \\
introduction on their roles and responsibility towards tax? & \\
\hline Category of responses & Number & Percentage (\%) \\
Yes & 67 & $89 \%$ \\
No & 8 & $11 \%$ \\
\hline \multicolumn{4}{l}{} \\
\hline Question 21: Do you think that it will be better if students are given an early information on \\
the benefit of tax to society? \\
Category of responses & Number & Percentage (\%) \\
Yes & 67 & $89 \%$ \\
No & 8 & $11 \%$ \\
\hline
\end{tabular}

In order to gain more specific information as to when tax education is best introduced to the young, $84 \%$ of respondents agreed that it should be introduced at the secondary level. $6 \%$ of them do not agree with the first group's opinion and believe it should be introduced at the primary school level. Another 6\% do not think it should be introduced at both levels.

\begin{tabular}{lcc}
\hline \multicolumn{2}{l}{ Question 22: At what level do you think tax education is suitable to be introduced? } \\
\hline Category of responses & Number & Percentage (\%) \\
At secondary school level & 62 & $84 \%$ \\
$\begin{array}{l}\text { At primary school level } \\
\text { Both not suitable }\end{array}$ & 4 & $6 \%$ \\
$\begin{array}{l}\text { Others: } \\
\text { Introduced tax program with IRBM }\end{array}$ & 4 & $6 \%$ \\
$\begin{array}{l}\text { collaboration } \\
\text { If in primary school, introduce on basic }\end{array}$ & 1 & $1 \%$ \\
$\begin{array}{l}\text { knowledge about reason and benefit of tax. In } \\
\text { secondary school, more detail and technical }\end{array}$ & 1 & $1 \%$ \\
$\begin{array}{l}\text { Best introduced in university } \\
\text { Incorporate in working place orientation } \\
\text { program }\end{array}$ & 1 & $1 \%$ \\
\hline
\end{tabular}

To conclude Section V of the survey, respondents were asked, in Question 23, to rate the importance of tax knowledge as compared to other financial literacy elements. In terms of 'significantly important' level, findings shows that 'knowledge on tax management and record keeping' was ranked only fourth (25 responses), compared to other knowledge. A majority of respondents only perceived tax knowledge as 'very important'. Knowledge on personal financial management' was ranked first (75), followed by 'knowledge on personal loan and credit cards' (34), 'knowledge on benefit and risk of online banking' (31) and 'knowledge on retirement fund' (28). It is important to highlight that personal financial literacy includes knowledge of making appropriate decisions such as investing, insurance, savings, budgeting, retirement and tax planning. In general, the above finding shows that respondents do not perceive taxation as among the most important knowledge in their personal financial decision. Taxation might affect personal financial decision of a taxpayer and without good understanding on tax and tax planning, a person's financial status and financial decision making, might be at risk [40]. 
Question 23: Of the following, please indicate which is the most important to least important to help you have a good financial understanding for making decisions about your future (with 1 being significantly not important and 5 being significantly important).

\begin{tabular}{|c|c|c|c|c|c|}
\hline & $\begin{array}{l}\text { Significantly } \\
\text { important }\end{array}$ & $\begin{array}{c}\text { Very } \\
\text { important }\end{array}$ & Important & $\begin{array}{c}\text { Not } \\
\text { important }\end{array}$ & $\begin{array}{l}\text { Significantly } \\
\text { not important }\end{array}$ \\
\hline $\begin{array}{l}\text { Knowledge on } \\
\text { retirement fund }\end{array}$ & 28 & 17 & 24 & 4 & \\
\hline $\begin{array}{l}\text { Knowledge on } \\
\text { personal financial } \\
\text { management }\end{array}$ & 57 & 13 & 5 & & \\
\hline $\begin{array}{l}\text { Knowledge on tax } \\
\text { management and } \\
\text { records }\end{array}$ & 25 & 25 & 21 & 3 & \\
\hline $\begin{array}{l}\text { Knowledge on } \\
\text { personal loan and } \\
\text { credit cards }\end{array}$ & 34 & 12 & 19 & 5 & 3 \\
\hline $\begin{array}{l}\text { Knowledge on } \\
\text { benefit and risk of } \\
\text { online banking }\end{array}$ & 31 & 23 & 15 & 2 & \\
\hline
\end{tabular}

\subsection{Section VI - Opinion on Malaysian tax administration}

The final section of the survey assessed respondents' opinion on tax administration in Malaysia. The following questions were asked to probe their perception:

24. What is your satisfaction level with the Malaysian tax system?

25. What is your opinion on the distribution and effectiveness of tax collection management in Malaysia?

26. What is your opinion on the fairness of the Malaysian tax system?

27. The IRBM has used a tag line "You Are the Nation's Hero" to represent the taxpayer who has willingly fulfil his/ her responsibility towards complying with tax. Do you agree with this statement?

Generally, a majority of respondents are satisfied with Malaysian's tax system. It shows that $55 \%$ of them rated their satisfaction level as 'Satisfied' and 7\% as 'Very Satisfied'. Only $15 \%$ was below the satisfied level and interestingly $23 \%$ claimed that they are neutral. In terms of their perception on the effectiveness of collection and distribution of taxes, $43 \%$ and $3 \%$ of respondents ranked it as 'Effective' and 'Very Effective', whereas only $20 \%$ ranked is as below the effective level. The respondents' opinion on the fairness of Malaysian tax system, were as follows: $29 \%$ and $3 \%$ of respondents ranked the tax system as 'Fair' and 'Very Fair". In total 30\% of the respondents found the tax system in Malaysia not fair and $39 \%$ of them are neutral. Many previous studies suggest that inadequate tax knowledge also led to taxpayers' negative perception towards the fairness of a tax system [41] and contributed to non-compliance behaviour. 


\begin{tabular}{lcc}
\hline \multicolumn{3}{l}{ Question 24: What is your satisfaction level in the Malaysian tax system? } \\
\hline Category of responses & Number & Percentage (\%) \\
Very satisfied & 5 & $7 \%$ \\
Satisfied & 42 & $55 \%$ \\
Neutral & 17 & $23 \%$ \\
Not satisfied & 9 & $12 \%$ \\
Very not satisfied & 2 & $3 \%$ \\
\hline
\end{tabular}

Question 25: What is your opinion on the distribution and effectiveness of tax collection management in Malaysia?

\begin{tabular}{lcc}
\hline Category of responses & Number & Percentage (\%) \\
Very effective & 2 & $3 \%$ \\
Effective & 32 & $43 \%$ \\
Neutral & 27 & $36 \%$ \\
Not effective & 11 & $15 \%$ \\
Very not effective & 3 & $4 \%$ \\
\hline \multicolumn{2}{l}{ Question 26: What is your opinion on the fairness of the Malaysian tax system? } \\
\hline Category of responses & Number & Percentage (\%) \\
Very fair & 2 & $3 \%$ \\
Fair & 22 & $29 \%$ \\
Neutral & 29 & $39 \%$ \\
Not fair & 17 & $23 \%$ \\
Very not fair & 5 & $7 \%$ \\
\hline
\end{tabular}

The final question of the survey highlighted a slogan used by the IRBM in order to encourage and appreciate taxpayers' contribution and responsibility towards paying tax. "You Are the Nation's Hero" has been used by the IRBM with the intention is to ensure that taxes will be viewed not only as a revenue collection mechanism, but also as a fundamental component in the development and progress of a nation. It was found that $51 \%$ of respondents agreed to the statement and $17 \%$ of them disagreed. This interpretation appears to support the needs for better understanding of the fundamental element of taxation in order to increase voluntary compliance and promote a powerful taxation regime.

Question 27: The IRBM has used a slogan of "You Are the Nation's Hero" to represent the taxpayer who has willingly fulfilled his/her responsibility towards complying with tax. Do you agree with the statement?

\begin{tabular}{lcc}
\hline Category of responses & Number & Percentage (\%) \\
Agree & 38 & $51 \%$ \\
Disagree & 13 & $17 \%$ \\
Not fully agree & 24 & $32 \%$ \\
\hline
\end{tabular}




\section{Conclusions}

\subsection{Tax education experience during secondary school}

After so many years, Malaysia has yet to establish and implement formal tax education in Malaysia's secondary school. Respondents who graduated from secondary school since 10 to 40 years ago provided consistent responses on the lack of tax education experience. More than $90 \%$ of respondents claimed that they did not received any formal tax education in school nor were involved with any collaborated tax education program with the IRBM. Even though all respondents came from government secondary schools, the low rate of tax education's exposure either formally or informally needs serious attention. A government school is expected to entrust government policies to its citizen through its education system. However, even though some subjects in secondary school (economic and accounting) integrate tax education elements, this does not fulfil the definition of tax education itself. As suggested by previous studies, tax should be perceived as a universal subject, and should be taught as a core subject instead of an elective [4], [6].

The informal tax education is also expected to be highly exposed to government schools that have more facilities and higher accessibility to other tax related parties such as IRBM. However, this claim seem to mislead since none of respondents from the age of 25 to 58 years old have had experience in any collaboration program between the IRBM and the participants' secondary school. Even though IRBM and MOE had jointly organised "Kem Cerdik Cukai" (Young Tax Camp) through the Malaysian Tax Academy since the year 2011, this tax education program does not cover all secondary schools in Malaysia. It is held only once a year and caters to only 200 to 300 participants including school teachers from selected school. As this findings reveal a fundamental gap in the dissemination of tax education to secondary school students. Improvement to the IRBM's informal tax education program and reform associated with the secondary school curriculum is highly warranted.

\subsection{Ascertain whether the public desire a compulsory form of taxation education during their secondary schools}

The low level of tax compliance among individual taxpayers and its implication towards future tax collection has triggered the attention of tax regulators and tax educators in Malaysia. Working closely with tax professional associations such as the Malaysian Association of Tax Accountant (MATA), tax educators were invited to provide insight on the Malaysia National Budget 2020. This has opened up an opportunity for discussion on the needs of tax education reform at a higher level between MOE, IRBM and MOF. To provide some insights on this issue, this study has initiated a survey with the intention to gather information from the public as to the need and importance of tax education at the secondary school level.

The findings of the survey shows that a majority of respondents are in favour towards formally introducing tax education at the secondary school level. Tax education is very important since it is able to solve most of problems related to compliance by improving tax 
literacy of potential future taxpayers. Ensuring adequate tax education in secondary school will improve awareness and inculcate tax responsibility in our future taxpayer. Tax education is also able to enhance taxpayer knowledge towards ensuring voluntary compliance since they are aware of their rights and responsibility. Through tax education, taxpayer confidence level in the information they provide to the, IRBM will also increase in order to avoid unintentional non-compliance. More importantly with better tax knowledge, the taxpayer will be able to understand the consequence of tax evasion and will pay tax accordingly in order to ensure sufficient tax collection for the country.

Therefore, the government should take very serious attention to the public's suggestion of a compulsory form of tax education for the young generation in Malaysia. As emphasis by previous studies, early tax education is important as it teaches young people to respect the tax system and understand the requirement of having to pay tax when they become liable [4], [6], [25]

\subsection{Determine the confidence levels of the public's experience in filing their tax return}

The basic objective of the introduction of the Self-Assessment System (SAS) is to promote voluntary tax compliance since taxpayers themselves need to assess their income and must be responsible with the information provided to the IRBM. Under this tax regime, a taxpayer is required to have adequate tax knowledge and updated information on the changes of tax policies in order to comply with tax laws. The third objective of this study is to assess taxpayers' confidence level in filing their tax return. The finding shows that taxpayers have low level of tax knowledge when they first left the secondary school. However, within the period that they become liable to pay tax, they have gained more information and increased their tax knowledge. As there is lack of formal tax education at the secondary school level, the additional tax knowledge that they gained, comes from informal tax education provided by IRBM. Despite the increased tax knowledge, it was found that $55 \%$ of participants still sought other's help or paid someone else to file the tax return on their behalf. $38 \%$ of respondents confessed that they are not confident with the information they provided in their tax returns. Besides confirming the disadvantages of informal tax education being unable to reach every taxpayer, this study also put more emphasis on the importance to enhance the effectiveness of tax education program provided by the tax authority.

The most significant impact of this survey is it provides concrete reason for a formal tax education to be established by the MOE in order to prepare a solid ground of fundamental tax education for Malaysia's future taxpayers. It is important to continuously increase taxpayers' confidence level through adequate tax knowledge since lack of confidence might cause tax anxiety, filing error or incomplete tax returns.

\subsection{Identify public perception on the importance of tax knowledge as compared to other areas of financial literacy}

As the main purpose of this study is to encourage the introduction of formal tax education into secondary school, it is crucial to determine public's perception on the importance of tax knowledge. This study provides credible findings as the opinions were given by matured taxpayers who have both tax administrative and financial decision 
experience. Analysis of the responses shows that the majority of participants do not perceive tax knowledge as important as the other areas that constitute financial literacy definition. This finding suggests that respondents are not aware that taxation is the foremost important aspect of financial literacy as they have less knowledge on the concept of disposable income or aftertax income. They should be educated to the fact that an individual's decision to spend, save or invest should be based on their disposable income, which is the money left after all taxes are deducted.

This study has managed to highlight the extent to which tax aspect currently being incorporated in other financial literacy knowledge and the possible reason why it has been excluded or ignored by the taxpayer. Taxpayers who did not perceived taxation knowledge as important, will not only increase risk his or her own individual financial status, but more significantly has the potential to affect the revenue of a country.

Although this study has answered its research questions and achieved its objectives, there were some unavoidable limitations to be considered and improve in future research. Utilisation of this study's finding is principally limited due to the small sample size of the respondent group. There are also incomplete responses in the survey that resulted in anomalous data. This may be due to recruitment and distribution of the survey using social media. As such, the observations reported in this study are confined to raw data evaluated. Even though academic literature indicates that tax education in secondary school would benefit the larger population, the small and not fully random sampling of this study limits the generalisation of this study to the whole Malaysian public. However, these limitations provide future opportunity for further comparative research through larger sample size to examine the accuracy of the assertions made in this study. Finally, data from this study were only descriptively analysed. To further expand and bring more emphasis on the importance of this study, future research should provide inferential statistics and analysis to increase accuracy and robustness of the findings.

Since 'Education is the Key to Success', the most effective strategies to manage tax compliance problem should also be solved through ensuring adequate tax education towards the current and future taxpayer. Informal tax education provided by IRBM is very limited as it is unable to reach all levels and types of taxpayers. Therefore, the MOE could shoulder this responsibility and ensure formal tax education through Malaysia's school education system. As all Malaysian has to go through the same school system, the chances to effectively disseminate tax knowledge and continuously improve tax compliance level among taxpayer are very high. As many studies support the motion that moral and ethical factors are more dominant in determining taxpayers' compliance attitude, this study also suggest for formal introduction of tax morality education at primary school level. Moral responsibility towards tax should be exposed through fun tax education programs such as games and animation tax story. Having awareness on tax responsibility will help them to absorb the more technical aspects of tax system once they enter the secondary school tax education system. Since the process of establishing a formal tax education framework and its implementation will take time to materialise, other subjects such as moral studies or civics should be consider to formally integrate tax education in secondary and primary school. 


\section{References}

[1] OECD, Building Tax Culture, Compliance and Citizenship. 2015.

[2] A. H. Diaz-Rivillas, Borja \& Lindemberg-Baltazar, "EDUCACIÓN FISCAL Y CONSTRUCCIÓN DE CIUDADANÍA EN AMÉRICA LATINA,” Receita Fed. Estud. Tribut. e Aduan., 2014.

[3] M. E. Kornhauser, "A tax morale approach to compliance: Recommendations for the IRS," Florida Tax Rev., 2007.

[4] B. Barjoyai, "Tax Illiteracy in Malaysia: Problems and Solutions," J. Sch. Accountancy, MARA Inst. Technol., vol. 11, no. 2, pp. 6-35, 1992.

[5] K. Eriksen and L. Fallan, "Tax knowledge and attitudes towards taxation; A report on a quasi-experiment," J. Econ. Psychol., 1996.

[6] N. Jeyapalan Kasipillai, "The Influence of Education on Tax Avoidance and Tax Evasion," eJournal Tax Res., 2003.

[7] F. Jacob, "An Empirical Study of Tax Evasion and Tax Avoidance: A Critical Issue in Nigeria Economic Development," J. Econ. Sustain. Dev., 2014.

[8] P. Alexander, M. Balavac, S. Mukeherjee, A. Lymer, and D. Messey, "Improving Tax Literacy and Tax Morale of Young Adults," 2018.

[9] A. Kalafunja and E. Swai, "Integrating tax education in the primary and ordinary level secondary education curriculum in Tanzania," 2016.

[10] J. Joyner, "US and European tax rates and compliance," http://www.acus.org/new_atlanticist, 2009. [Online]. Available: http://www.acus.org/new_atlanticist.

[11] P. Hite and J. Hasseldine, "A primer on tax education in the United States of America," Account. Educ., 2001.

[12] L. Koster, "The Incorporating of Basic Tax Education in the Secondary School Curriculum," Thesis Univ. Pretoria, 2012.

[13] E. Lee, "The State of Nation: Considerations in reforming Malaysian's tax system," The Edge Malaysia, p. $24,2018$.

[14] N. Bărbuță-Misu, “A Review of Factors for Tax Compliance,” Econ. Appl. Informatics, 2011.

[15] O. Rani Diana, "The impact of forensic accounting, investigation and audit on tax compliance in Malaysia," Edith Cowan University, WA, 2011.

[16] E. Kirchler, E. Hoelzl, and I. Wahl, "Enforced versus voluntary tax compliance: The 'slippery slope' framework," J. Econ. Psychol., 2008.

[17] E. C. Loo, C. Evans, and M. McKerchar, "Challenges in understanding compliance behaviour of taxpayers in Malaysia," Asian J. Bus. Account., 2010.

[18] K. Beron, H. V. Tauchen, and A. D. Witte, Why People Pay Taxes: Tax Compliance and Enforcement. University of Michigan Press, 1992.

[19] J.-S. Lee and K. M. Carley, "Predicting Intentional Tax Error Using Open Source Literature and Data," SSRN Electron. J., 2016

[20] J. K. Ho, "An Overview of Tax Education Requirements," J. Sch. Accountancy, MARA Inst. Technol., vol. 11, no. 2, pp. 43-55, 1992.

[21] A. Barieyah Mat Bahari and L. Ming Ling, "Introducing Tax Education in Non-Accounting Curriculum in Higher Education: Survey Evidence," J. Financ. Report. Account., 2009.

[22] M. L. Lai, Y. Zalilawati, M. M. Amran, and K. F. Choong, "Quest for tax education in non-accounting curriculum: A Malaysian study," Asian Soc. Sci., 2013.

[23] N. Hassan, A. Nawawi, and A. S. A. Puteh Salim, "Improving tax compliance via tax education - Malaysian experience," Malaysian Account. Rev., 2016.

[24] M. A. Norazah, "The self-assessment tax system: The perception of academicians.," Universiti Teknologi MARA, 2006

[25] A. Furnham, "Understanding the meaning of tax: Young peoples' knowledge of the principles of taxation," J. Socio. Econ., 2005.

[26] N. Saad, "Tax Knowledge, Tax Complexity and Tax Compliance: Taxpayers' View," Procedia - Soc. Behav. Sci., 2014.

[27] S. Ojo, Elements of tax management and practice in Nigerai. Lagos: Sagribra Tax Publications, 1998.

[28] J. U. B. Azubike, "Challenges of tax authorities, taxpayers in the management of tax reform process," The NIgerian Accountants, pp. 36-42, 2009.

[29] P. Bardsley, "Tax compliance research: An economic perpsective on the research agenda," Aust. Tax Forum, vol. 11, pp. 271-290, 1994.

[30] R. Cerqueti and R. Coppier, "Corruptibility and tax evasion,” Eur. J. Law Econ., 2015.

[31] "Increase in taxpayer below 40 years old," Berita Harian, 2019. 
[32] G. Nwanna and D. Richards, "The Imperative Of Basic Tax Education For Citizens," Am. J. Bus. Educ., 2010.

[33] R. Oberholzer and M. Nel, "The Road to an Improved Tax Curriculum in South African Schools," Educ. as Chang., 2006

[34] T. K. Sarker, "Improving tax compliance in developing countries vis self-assessment systems - what could Bangladesh learn from Japan," Asia-Pacific Tax Bull., vol. 9, no. 6, pp. 3-34, 2003.

[35] R. Curtin, S. Presser, and E. Singer, "The Effects of Response Rate Changes on the Index of Consumer Sentiment," Public Opin. Q., 2000.

[36] J. S. Armstrong and T. S. Overton, "Estimating Nonresponse Bias in Mail Surveys," J. Mark. Res., 1977.

[37] C. Bazart and M. Pickhardt, "Fighting Income Tax Evasion with Positive Rewards: Experimental Evidence," 2009.

[38] B. Kastlunger, S. G. Dressler, E. Kirchler, L. Mittone, and M. Voracek, "Sex differences in tax compliance: Differentiating between demographic sex, gender-role orientation, and prenatal masculinization (2D:4D)," J. Econ. Psychol., 2010.

[39] M. R. Palil, "Tax Knowledge and Tax Compliance Determinants in Self Accessment System in Malaysia," J. Int. Dev., 2010.

[40] T. Brackin, "Taxation as a component of financial literacy: How literate are Australians in relation to taxation," Griffith University, 2014.

[41] G. Gilligan and G. Richardson, "Perceptions of tax fairness and tax compliance in Australia and Hong Kong - a preliminary study," J. Financ. Crime, 2005. 